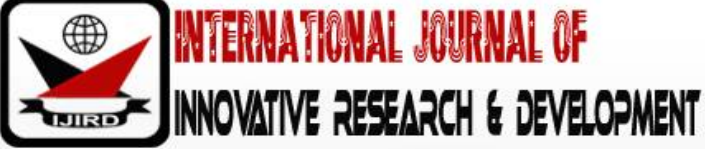

ISSN 2278 - 0211 (Online)

\section{The Influence of Russian Communism and the Case of the Red Terror in Some Selected Cities of Ethiopia during the Military Government (1974-1991)}

\author{
Bitwoded Admasu Dagnaw \\ Assistant Professor, Department of Civics and Ethical Studies, University of Gondar, Ethiopia \\ Dejen Abera Tsegaye \\ Assistant Professor, Department of Civics and Ethical Studies, University of Gondar, Ethiopia
}

\begin{abstract}
In the year 1974-1991, Ethiopia experienced a government of military dictatorship with a socialist ideology. The military junta led by colonel Mengistu declared Ethiopia a socialist state in which the central government had an undivided ultimate right on all aspects of economic, social, and political life of the state. After welcoming the Soviet political and military advisors with their leading cadres and activists, all sectors of the country's economy were turned state owned and command economy was established. The military junta ensues on to rule Ethiopia with decrees and proclamations with the then popular slogan called 'Ethiopia Tikdem'. Snatching the political power of the people, the military junta faced violent resistance and armed struggle as well as urban guerilla. The military junta was responsible for human rights violation on enormous scale including the torture, murder and disappearance of tens of thousands of Ethiopians mainly during the year (1978-1979). This period dubbed the red terror. The red terror campaign was launched by Mengistu with a cruel and horrible speech delivered in Revolutionary Square in the heart of Addis Ababa. Almost all provinces in the country were indiscriminately affected by the terror as well as the torch. However, some major selected cities were the major victims of the torch and the terror. In response to the urban guerrilla attacks alleged by the Ethiopian People's Revolutionary Party, Colonel Mengistu declared that for every Revolutionary killed, the Derg would respond by killing thousands of counter Revolutionaries. This research deals about The Influence of Russian Communism and the Case of the Red Terror in some selected cities during the Military Government of colonel Mengistu (1974-1991).Since the research aims to understand the insight of the people who were very affected by the torch and terror, the study used qualitative research methodology. In terms of techniques of data collection methods, the researcher used open ended questioner, depth interview and six focus group discussions. In addition to these techniques of data collection methods, the research has used also Books and other related secondary sources such as archives. The findings of the research have shown that Peoples in a state of dictatorship and subjugation have neither freedom nor responsibility. The failure of the military junta to handover the political power to the Peoples' of Ethiopia resulted in the death of thousands of innocent along with those persecuted from 1978-1979. A significant number of students in all levels were slaughtered, and left exposed to vultures in the streets of many cities. The Derg relentlessly hunted down many young students in general and EPRP adherents in particular and thousands of people were killed and executed. Moreover, the adoption of socialist ideology in Ethiopia led to the closing of many churches which was a confusing period among the believers and the study also reveals that the adoption of socialist ideology manifested with the lowest level of economic growth and development by demanding the country's economy in to the war field.
\end{abstract}

Keywords: Red terror, socialist ideology, military junta, dictatorship

\section{Introduction}

The continent of Africa, stretching over a huge geographical area and gifted with varied natural resources, had always been a continent of particular attraction for outside powers. Africa has continued its struggle with renewed vitality and energy to establish an equitable, just, and durable international economic order and at the same time taking appropriate domestic economic measures to mitigate the adverse effects of the policies of the outside powers. Most African states have been experiencing major economic, political, and social problems. In this regard, it seems that the horn of Africa is one of the most conflict prone regions of Africa. In the case of Ethiopia, it is not uncommon to experience a vicious cycle of famine and civil war.

Although Ethiopians ancient past is scantily recorded in the passages of history, it has a history stretching back for more than three-thousand years. For instance, the earliest historical record dates back to the first century A.D. when the 
anonymous author of the Periplus of the Erythraean Sea encountered the Aksumite ancestors of the Ethiopians 1 (Markakis, 1974:2). The Solomonic dynasty which had existed throughout the Ethiopian history claimed its descendants from queen of Sheba and king Solomon of Israel. According to this legend, the queen went to Israel hearing the wisdom of King Solomon and later conceived a child from him who was afterwards called Menelik I. Even though legend, it is powerful because it shaped the Ethiopian history. As a result of this, Solomonic dynasty prevailed in Ethiopia for many generations. In addition to this legend, in the Old Testament of the Bible, the name Ethiopia has been repeatedly mentioned a number of times, giving rise to the claim of Ethiopia's existence in Biblical times and the myth of a history that is three thousand years old. According to Samuel, revolutions are rare. Most societies have never experienced revolutions, and most ages until modern times did not know revolutions (Huntington, 2016:1)

Any revolution which broke out in any country does have its own political impact in other parts of the word. When the international political system was dominated by two super powers during the cold war, the revolutionary explosions do have its own impact not only affecting the international political scenario but also it affects the international world order. The influence of the international political system on the Ethiopian politics is clear. For instance, the 1977/ 78 EthioSomalia war, the 1984 famine and the Western world economic aid and the Russian military assistance are some of them. Like any other countries Ethiopia's political alignment to any one of the western powers do have its own economic and political interest. Ultimately, in 1974 the socialist military government of the Derg² denied the last monarchic ruler of Solomonic dynasty Hialesillase and proclaimed Ethiopia a Socialist country. During three turbulent decades of the twentieth century revolution, civil wars, and guerilla warfare characterized Ethiopian history. All historical writings involve choice, it is necessary to emphasise that communism was once a wide spread global phenomena, and it was not only in Europe and Asia socialist experiment introduced but also assumed in some countries of Africa which seems to have important and contain some to teach us. In this case, the best example is Ethiopia, were communism introduced for nearly two decade the state become soviet satellite. A typical example of deceitful invocation of Marxism-Leninism was furnished by the Ethiopian dictator colonel Mengistu Haile Mariam who tried to transform the country in to a fully-fledged soviet satellite from the year 1974 up to 1991.

\subsection{The End of Haile Selassie Regime and the Coming to Power of Colonel Mengistu Haile Mariam}

Emperor Haile Sillasie ruled the country for more than forty years (1930-74). Despotically ${ }^{3}$ controlled complete political power for about forty-four years. It is crucial to say that in the past the Ethiopian people, completely isolated from the rest of the world and unable to benefit by the great current of modern civilization. Haile Sillasie who was a wise king introduced a constitution in 1931; however, it favoured only the feudal nobilities and dignitaries. Executive political decision and real power remained in the hands of the king who declared himself might of the trinity. The three branches of the government were not separated. Though created a bi-cameral parliament, the two chambers had only an advisory role. As a result of this his imperial rule was characterized by wide spread injustice, autocratic control of the legislature and judiciary and maintenance of an essentially feudal system in the country side. During the imperial regime, Ethiopia had observed sixty percent military support from the United States of America compared with other African countries (Medhane;2001).

The significance factor that shakes the throne of Hailesillasie according to Bahru was in 1960. Despite its failure, the coup represented the most serious challenge to his power between 1941 and 1974. It marked a watershed in the history of political opposition. Organized by the two brothers Mangestu and Garmame Neway, symbolizes the military and intellectual components of that opposition before as well as after 1960(Bahru;1994:211). According to Bahru, Garmame was the moving spirit behind the attempted coup. His record as a civil servant was one of a high sense of civic responsibility and concern for the underprivileged. This made him suspect in the eyes of the regime, and he was exiled to distant administrative posts, first in Walayta, then Jijiga. He converted these exile posts into stations experimenting in equitable administration(Bahru, 1991:213). In Walayta, he made efforts to ease the burden of the tenants by introducing a settlement programme, as well as written tenancy contracts. In Jijiga, too, he endeared himself to the Somali by taking measures to improve their lot. The obstruction he encountered even in these remote posts convinced him of the need for change, and he began to work on his brother to change the regime.

\footnotetext{
1Aethiopes meaning burnt faces in ancient Greek writings, especially recorded by Homer and Herodotus. The Indian Ocean was also known as the Ethiopian Ocean.

2Derg in Amharic means Committee. The Provisional Military Government of the Derg or committee declared Ethiopia a unitary state structure with a Socialist ideology. The military government soon adopted a command economic system through which any extra rural land and extra urban houses were put under the control of the state. The proclamation also put land under public ownership. The Derg ruled Ethiopia brutally with decrees and proclamations for more than twelve years.'

3Though created a bicameral parliament with two houses of Senate, the upper house and House of deputies, the lower houses, the two houses had an advisory role. Hence, the three branches of government were not separated. The emperor had an executive political decision-making role at zufan chilot after the senate and house of deputies discussed any economic and political matters of the state.
} 


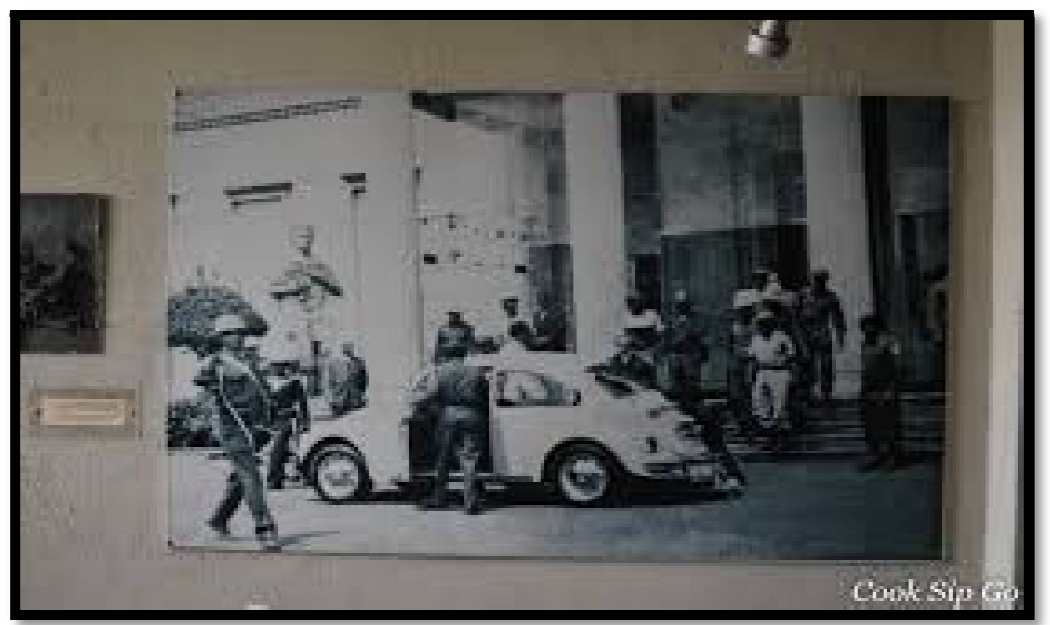

Figure 1: Emperor Hailesillasie I Dethroned from His Political Power and Taken to Custody (1974)

The torch of change that the rebels had kindled was not extinguished with their physical elimination. On the contrary, it sparked a more outspoken and radical opposition to the regime. Soon the most implacable opposition to the regime came from the students. The Ethiopian student movement went through various phases of evolution, starting as a cultural and intellectual forum of elite and growing into a mass revolutionary movement in the late 1960s and early 1970s. The escalation of government repression only succeeded in inciting students to ever bolder challenges to authority. Repression and opposition both grew in an ascending spiral, until they had their final resolution in the revolution of 1974. Students became politically active which centred on the University college of Addis Ababa. Primarily, their questions were campus issue but motivated by the 1960 coup det tat they began to ask ideological and political issues later on. The first manifestation of radical opposition came in February 1965. While parliamentarians debated the regulation of tenancy, students came out to the streets chanting the revolutionary slogan of "land to the Tiller". That event according to Bahru argued that a decade of student radicalism, punctuated by annual demonstrations exposing the inequities of what came to be characterized as the feudo-bourgeois regime in Ethiopia, and expressing solidarity with the anti-imperialist and anticolonialist struggles elsewhere in the world (Bahru; 1994:223).

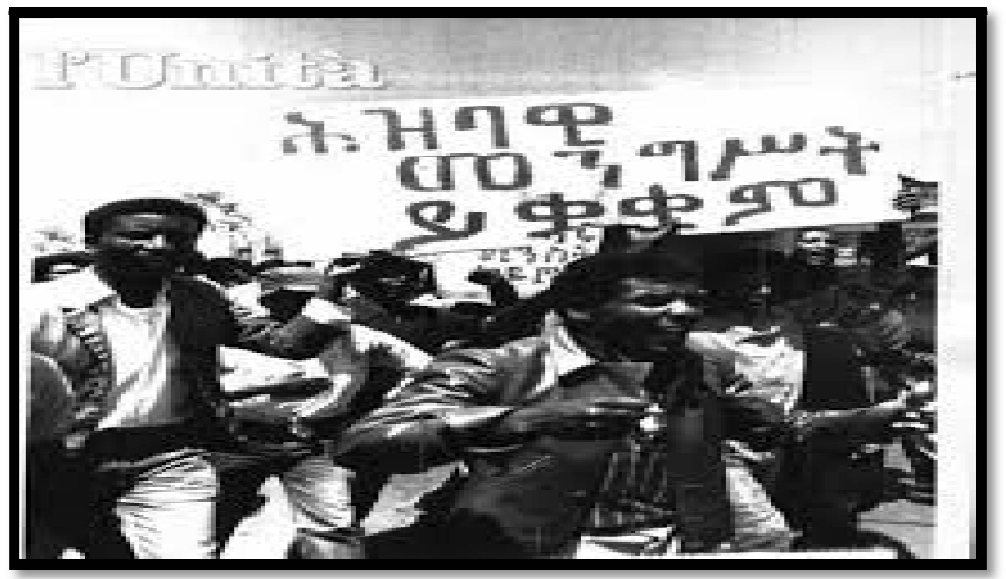

Figure 2

Addis Ababa University Students marching against the Hailessillasie regime demanding political rights in the early 1970's. confrontation between the government and student activists, outstandingly backed by the large majority of the student body in demonstrations and boycotts,reached its climax in the autumn of 1969.

A highly politicized 4 and militant student group began to study Marxism and started to condemn many aspects of the government's policy. Nevertheless, Wallelign who was a captive of others Anti-Ethiopian political agenda, emerged with an Article on the question of Nationalities that later published in the newspaper 'Struggle' on the 17th of November 1969 was utterly superficial and full of bais and prejudice. Wallelign's claim that the Amhara had suppressed all the other ethnic groups for the sake of the unity of Ethiopia is unscientific and baseless accusation because a broad masses in no means suppress a broad mass as history always clarifies. Through out the Ethiopian history, there have been an immense

4The remarkable weekly clandestine paper 'Democratia' started to appear. As to Balsvik, this political paper was produced by a movement of intelligentsia and students who were later to called themselves as the Ethiopian People's Revolutionary Party (EPRP). Later on, in mid-1974, another influential underground paper of the left, 'Yesefiw Hezb Demt's translated in Amharic as 'Voice of the Broad Masses', was produced by a group which was to be known as the All Ethiopian Socialist Movement (MEISON). The two political movements had their institutional origin, a few years earlier, in Ethiopian student politics in North America and Europe. Both papers propagated the ideology of Marxism-Leninism, the abolish of the monarchy, objection to a military government and the installment of people's government. 
socio-political interaction and amalgamation as well as assimilation of the Ethiopian people each other. Furthermore, the fact is entirely different from what walelign has said since every ethnic group in Ethiopia at present still maintain their own culture and language unlike the baseless accusation of that time. If the issue of assimilation is raised, it appears to be a give and take socio-cultural relationships of the various ethnic groups inside the country since society is an association of human groups whose members lived by common rules of condut. Forinstance the Oromo ethnic group have passed through a strong system of assimilation called Adoption and Mogassa. It seems that Wallelign's idea was first copied from the politics of the former United Soviet Socialist Republic. However, Stalinist Russia have used this concept of nationalities issue for temporary unification and integration political strategy of neighborhood nations. However, it has been imported and completely misinterpretted as a divide and rule strategy to destroy the unity of Ethiopia. There was infact class opperssion that every Ethiopian citizens arbitrarily suppressed in every aspect of the states socio-econoic and political circumstances. Initially, this class opperssion was first rejected by students at Addis Ababa University with their quest for equality and land to the tiller. According to Balsvik, the students had contributed significantly to creating whatever political consciousness existed when the crisis came in February 1974 that led, inexorably, to the demise of the imperial regime and this was preceded by a process of unrest among the lower ranks of army soldiers, which started with a mutiny in the town of Negelle in Borena (Balsvik, 2007:39). The birth of the modern elite has significantly distorted the intra-and inter-elite as well as the elite mass relations. As to Merera, Ethiopia's modern elite, initially an isolated voice, were able to become a major voice of change in the post-war period. Especially from the 1960s onwards a new phenomenon of elite competition and conflict began to take shape under greatly national and international circumstances (Merera, 2003:167). The embarking of socialism and the Soviet union'sexemplary how socialism can develop a country as an alternative force to what the revolutionaries of the time call the American capitalism also transferred to Ethiopia in the form of socialist experiment. Afterwards, two schools of thought were emerged in their own respective right that actually affected the political sentiment of most students. The Class Struggle Thesiswas the first that soon grew to influence the concern of many people. It based its arguments on the basic notions of Marxist theory of Class Struggle as the engine of history. Class based thesis divided the society largely as those who control the means of production and those without them. And the major dynamics of conflict at every society adhered to these economic ${ }^{5}$ categorizations everywhere and every time. According to this approach, the class contradiction analysis could be applied to explain the dominant social conflict in Ethiopia, the resolution of which also would resolve all other conflicts in the state.

The dominant class contradiction in Ethiopia, its resolution would bring all other conflicts alongside. Contradictions of any kind like ethnic, religion and gender were the entire natural outgrowth of the class conflict getting to be resolved with the resolution of the class oppression. Moreover, the class conflict thesis held that not only other conflicts but also other effects of the conflicts like poverty, ignorance, and all other social crisis persisting were the resultant effects of the major conflict of the class contradiction. It called, therefore, that a revolutionary party that would rally all disadvantaged sections of the society with the vanguard of the Ethiopian peasantry was to be organized. Soon the Ethiopian Peoples' Revolutionary Party,and the All Ethiopian Socialist Movement was emerged driving from the ideology of Marxism and Leninism. In addition to this parties another political groups like the Woz League, Abiotawi Seded, Marxist-Leninist Revolutionary Organization ${ }^{6}$ all were backing the agenda of class oppression thesis was embarked. Though all driven from the idea of Marxism and Leninism ideology the struggle for power and resource put them into violent war and conflict. The contending elites of Ethiopia have had separate interests of their own and never hesitated to advance these by any means available to them and the Ethiopian history and the history of the Ethiopian state seem to be the history of the contending elites struggle for power and influence,which is an endless conflict throughout successive Ethiopian regimes(Merera,2003:166).

The Ethiopian Peoples' Revolutionary Party the dominant and probably the most popular Revolutionary Organization, soon staged an urban armed move and engaged in rural guerilla warfare. EPRP's actions provoked a massive and ever bloody counter-terrorism by the provisional military administrative council. The military government of the Derg and its affiliated political organizations stood against Ethiopian People's Revolutionary Party(EPRP).The Nationality Question Thesis within the leftist school of Class Struggle Thesis did not deny that there had been conflicts that emanated from class distinctions but argued that the contradiction that would solve any conflicts should be the conflict among the Nationalities of Ethiopia. At the meantime, in 1973 was a disastrous period of drought in the province of Wello in the Northern part of the country. Many thousands of people died from famine. As a result, the broad masses, the army, the students, and trade unionist took the same side against the regime. Following that the military arrested former ministers of the Haile Sillasie regime. Eventually, in September 1974 the emperor was systematically overthrown in military coup. After the down fall of the absolute monarchy follows a confusing period of the military juntas that ruled Ethiopia with decrees as well as proclamations and every opposition was soon brutally crushed indiscriminately.

\footnotetext{
5Main boundaries between opposite social groups are drawn along economic positions. The classes in conflict were the feudo-bourgeoisie class supported by the state machinery, and the oppressed Ethiopian peasantry with the newly rising small group of working class in some urban centers. Trying, therefore, to pick up other conflicts as major and governing contradiction in Ethiopia would undermine the struggle against the feudo-bourgeoisie regime of Emperor Haile Sellase

${ }_{6}^{6}$ Marxist-Leninist Revolutionary Organization was established in the early 1970's by Tesfaye Mekonnen, (also founder of EPRP) the author of Yidres La Balatatariku, Tasfaye Makonnen (1985) Yedras LaBalatariku (May It Reach the Protagonist). Addis Ababa, Ethiopian. While the rest was attributed with col. Mengistu H. M. himself and the then Dr. Senay Lekie.
} 


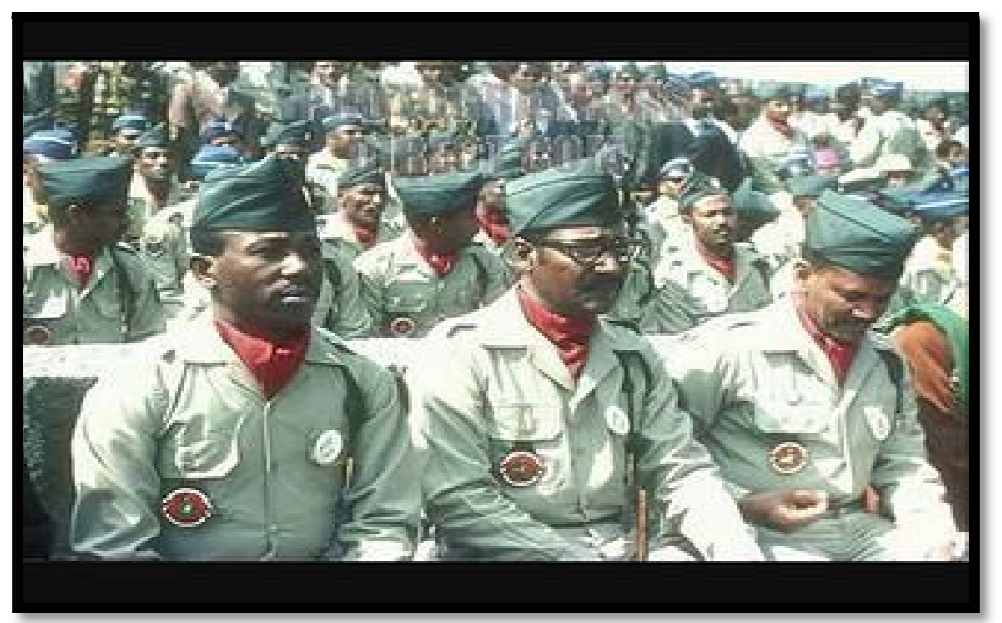

Figure 3: From Left to Right Col. Mengistu H. Col. Teferi B. \&Col. Atnafu A. (1975). All Fail Under His Ruthless Sword

Up to the year 1974 Haile Selassie maintained Ethiopia's alignment ${ }^{7}$ with the United States. The United States had been the principal supporter of Ethiopia, providing it with the largest amount of military assistance. According to Emerson, In the year between 1948 up to1964 was the largest allotted to any African states, reaching a cumulative total of \$ 81, 500,000 (Emerson,1966:14). Soviet Russian political strategy to Ethiopia was started with undermining Mengistu. At first, the Soviet Union provided military support to the Eritrean rebel opposition army and for Somali against Ethiopia by undermining Mengistu. As a result, to ensure his political and physical survival Mengistu was forced to appease and finally allied with Soviets. David put it in his own words, "as the major supporter of Somali and an in direct backer of the Eritrean rebellion, the Soviet Union clearly contributed to the threats that were most likely to topple Mengistu" (David, 1999:248).

The military leadership set up the provisional military administrative council called committee to govern the country. Mengistu who was only a major in the army appeared and became the leading figure by establishing Derge ${ }^{8}$. Mengistu began its operation with the active involvement and advice of the Soviet Russia declaring Ethiopia a socialist country. The Derg pressed the Soviet Union to replace the United States as Ethiopia's principal supporter and transformed Ethiopia alone Marxist-Leninist lines and followed the Soviet lead in foreign policy. Every communist country or party has its own specific history and its own particular regional local variations, but a linkage can always be traced to the pattern elaborated in Moscow in November 1917 which forms a sort of genetic code of communism. Russia was considered as a directive force that provides fresh and careful guidance for countries that introduced its experiment by especially sending its political cadres and military advisors. An obscure ordnance officer in his mid-thirties from all communities of the most oppressed small communities of Southern Ethiopia, Mengistu was catapulted to the highest levels of state power in the midst of political turmoil in 1974(Gebru,2016:311). The event marked the end of monarchism and inaugurated a new era of Republicanism, and characterized by militarization, terror, war, and dislocation, on a large scale. Mengistu's unceremonious exit in May 1991 was as dramatic as his unanticipated climb to power as he put it in his own words "Ourrise was spectacular; so was our fall". It was also dramatic in that it marked the end of the socialist experiment in Ethiopia just as his rise signalled the end of the monarchical regime.

\subsection{The Adoption of Socialist Experiment and Ethiopia's Experience of Socialism Under Mengistu And theRed Terror}

The 1974 revolution ${ }^{9}$ was arguably the most pivotal event in contemporary Ethiopian history. It was a paroxysm that shook the country as no other event had done in a hundred years since the formation of the empire state (Gebru, 2016:34)

"Political power grows out of the barrel of a gun" Mao Zedong

At the outbreak of the 1974 revolution, there was a sparkle of hope among some of the Derg military members that the Eritrean dissidents would lay down their arms following the demise of the monarchical regime. The Derg chairman, Lt. General Aman Andom had toured the region in August and September 1974 and presented to the Derg a comprehensive package of recommendations for administrative reform, economic development, and political reconciliation (Bahru, 1991:257).

"One hopes that the terror has defeated itself by teaching its opposers and the survivors that never again should such methods be employed whatever the situation or justification. This is the only way to defeat the DERG once and for all, to deny the terror any chance of resurrection' (Babile; 1992:210).

The Red Terror ${ }^{10}$ was a period of political repression and mass killings carried out by Bolsheviks after the beginning of the Russian Civil War in 1918. The Derg military junta did not start out the red terror. As Babile argues it had its prelude such

\footnotetext{
${ }^{7}$ Alignment occurs when a state brings its foreign policy goals and objectives with the other state to achieve its economic and political end.

${ }^{8}$ Amharic word meaning committee or council.

9The 1974 revolutions was led from the centre by radical military officiers later called themselves the Derg. Adhered to Marxism-Leninism and used the state's resources and tools of control political power. It was a top-down revolution that relied heavily on force and compulsion.

10The term is usually applied to Bolshevik political repression during the whole period of the Civil War (1917-1922), as distinguished from the White

Terror carried out by the White Army Russian and non-Russian groups opposed to Bolshevik rule against their political enemies. It was modeled on the Terror of the French Revolution. The Cheka (the Bolshevik secret police) carried out the repressions of the Red Terror.
} 
as summary executions, arbitrary killings, selective murders, a massacre here, carnage there, prisons filling up slowly and steadily, a time of small terrors. The red terror was one big orgy of violence, an example of epic lawlessness. The red terror was an open and arrogant denial of any rule of law, any notion of due process. It was summary justice and consequently gross injustice. Anyone could be tortured or killed for any reason. The executors of the red terror were thus omnipotent and from this situation most of them, in reality deranged and puny individuals, got their kicks, they enjoyed the power they wielded; they were mini-Mengistu in their own turfs or kebeles. By the name of resisting the assault that came from EPRP urban guerrilla warfare, the Derg planned a systematic strategy led by major Getachew Shibeshi to hunted down the members of the Marxist-Leninist Revolutionary Organization and its leaders as well (Tesfaye,1985:277).

After welcoming the Soviet political advisors with their leading cadres and activists, Mengistu turned all sectors of the country's economy state owned; and nationalized all sectors of the country's economy with the establishment Command economy as well. Following this a statue of Vladimir Lenin, Karl Marx and Mengistu's photographs were erected in different corners of the country. All forms of literature, the media and art were controlled and censored. Freedom of expression was brutally crushed. Relations and political alliance to Socialist countries increased and encouraged while any forms of political relation to the Western and the United States prohibited. Russian socialist political influence steadily grew in to the country. A book of political science that taught only socialist ideology ${ }^{11}$ was published and put in to effect in every academic environment. "By means of systematic propaganda, Moscow projected a favourable image of communism abroad (Pipes, 1995:305). During the years 1976-1989 the Ethiopian government continually imported tons of armaments to fight its external and domestic enemies and was in fact able to pacify the whole countryside. However, the longer the civil wars, the greater the need for arms, because part of what is imported was destroyed in combat and part of it was seized by the rebels.

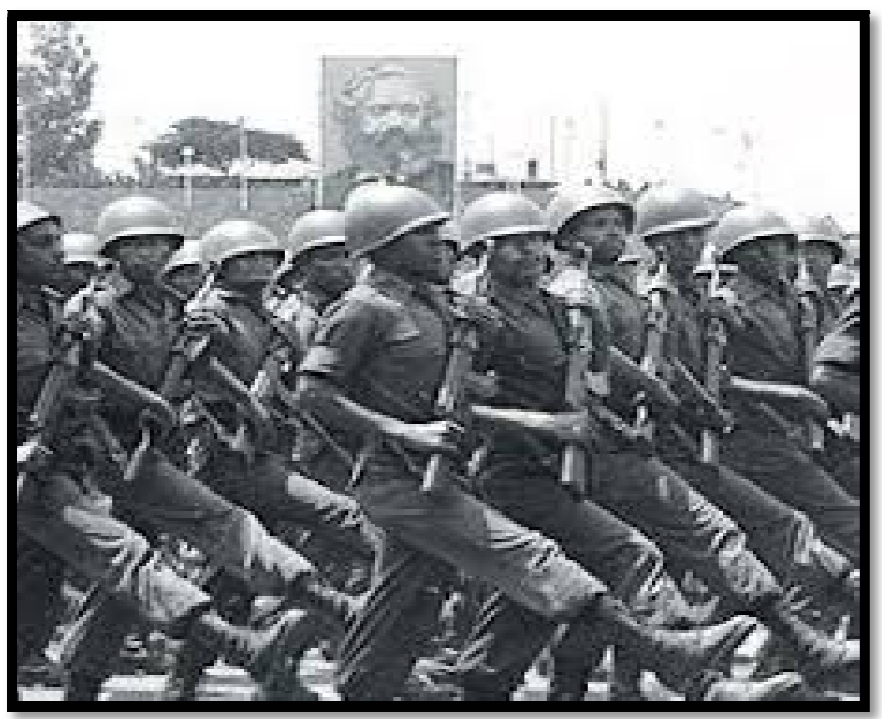

Figure 4: The Ethiopian Revolutionary Army Marching at the Revolutionary Red Square(1974-1991)

The economic and social costs were high and the political consequences severe because the military expenditures took away funds from much needed programs for improving the living conditions of the population. Almost everything the war machine consumed was purchased from outside and it consumed a lot at a cost that was exorbitant for a country that could not even feed its own people. By making arms obtainable on credit, the soviets helped prolong the war, further impoverishing the country. As to the military support, many countries, including Bulgaria, Czechoslovakia, East Germany, France, Hungary, Italy, Romania, Yugoslavia, and North Korea contributed to Ethiopia's military arsenal, but the bulk of it came from the USSR, either through procurement or outright grant (Gebru 2016:112)

According to Gebru, the Soviets began refitting Ethiopia's military in 1977 by selling much of what the revolutionary soldiers needed or wanted to acquire from water canteens and pistol holsters to T-62 tanks and MiG-23 fighter jets. It appears that between 1977 and 1991, Ethiopia purchased and obtained in excess of 300 aircraft and helicopters of various types and functions, 17 vessels and fast boats, 1700 tanks, 2975 armored personnel carriers, 4000 combat vehicles and trucks, 41740 light and heavy machine guns, 1172 cannons, 3915 mortars, 14738 antitank and 1605 antiaircraft guns, 400 rocket launchers and missiles, and 1,551,400 assault rifles(Gebru 2016:113)

A new National Anthem was introduced that honoured Socialism in general, Ethiopia in particular. Many students were sent to Socialist countries to study socialist ideology mainly to Cuba and Russia. The socialist military government tried to implement a carbon copy of a Soviet type communism in all its efforts. As a matter of fact, the main distinguishing characteristic of Ethiopia's experience of socialism under Mengistu was the red terror campaign. The Derg was responsible for human rights violation on enormous scale including the torture, murder and disappearance of tens of thousands of Ethiopians during the year 1976-78. Estimates for the total number of people killed in Ethiopia during the Red Terror for the initial period of repression was very large number. Yet, no accurate date is obtained since no one has made

${ }^{11}$ Socialist ideology is an economic and political system based on Marxism and Leninism and aimed to create economic and political equality among citizens. The premise is not bad at all the problem comes when implemented. 
rigorousresearch in this area previously. Estimates, however, for the total number of victims of young educated class especially EPRP members vary widely. This period was known as the red terror. Some sources from the then military government side reveals that the Ethiopian People's Revolutionary Party (EPRP) began white terror which was an assault aimed at higher military officials of the communist leaders inside the capital Addis Ababa and in different parts of the country's urban centres.

In response to the white terror the military dictator declared the red terror by which thousands of students were violently crushed as it was modelled from the features of Stalin's political terror. Any opposition party brutally crushed without any alternative opinion and most of the members of the Derg politburo mainly those who had the power to decide on policies were also assassinated. Army officers who were suspected having connection with the rebel armed groups of Eritrean People's Liberations Front were also imprisoned and later put to death. Many were killed because of their ideological difference. Even though, Diilas, a Yugoslavian considered Stalin as one of the cruellest and most despotic figures in history, of its many characters such as in an abuse of human rights, Socialist Mengistu of Ethiopia could be compared with Stalin of Russia. Despite the fact that in Stalin Russia millions of its citizens just disappeared, most died, many were sent to Siberia. According to Khrushchev, "Stalin was a profoundly sick man who suffered from suspiciousness and persecution mania" (Khrushchev, 1947). In similar manner this was true of Mengistu of Ethiopia who was ruthlessly assassinated loyal communist and his own associate friends' one after the other. After having Haile Sillasie killed Mengistu's years in office was marked by a totalitarian style government. The Countries massive militarization was financed by the Soviet Union, Cuba and the Eastern Block. From 1977 through early 1978, thousands of suspected enemies of the government were tortured and killed in a massive purge called the red terror. Mengistu gave the secret police and local governments' unchecked authority in arresting, detaining, torturing and murdering suspected enemies of the revolution.

Mengisu Haile Mariam's dictatorship killed thousands of intellectuals, students and school children in the process of wiping out civilian opposition. Parents were even forced to pay for the bullet that had killed their children, and not mourn their dead in the traditional way. Thousands were imprisoned, tortured or fled the country. The number of lives that were lost is very uncertain and, in some instances, probably highly exaggerated (Babile Tolla;1989).

The most conservative estimate states that at the very least several thousand people were killed, and thousands more imprisoned. Kiflu Tadesse, who obtains his numbers from the investigating commission that arrived after the fall of Mengistu's regime, says that approximately 55,000 were killed in Addis Ababa alone, and that towns all over Ethiopia witnessed the killing of pupils and teachers. In response to the guerrilla attacks against the military government of Mengistu by the Ethiopian People's Revolutionary Party ${ }^{12}$, Mengistu declared that for every revolutionary killed, the Derg would respond by killing thousands of counter revolutionaries. The red terror ${ }^{13} \mathrm{campaign}$ was launched by Mengistu with a cruel and horrible speech delivered in Revolutionary Square in the heart of Addis Ababa. The terror was officially launched by the Derg in 1976 when it declared open war against the Ethiopian People's Revolutionary Party(EPRP) and all those who had fought the imperial regime and who now refused to accept the authoritarian military rule as enemies of the people the Derg carried the conflict further into the realm of violence(Babile,1989:41). Unlike the above political fact stated by Babile some Derg official refuted and argue that the red terror was a response of the white terror which was first launched by members of Ethiopian People's Revolutionary Party (EPRP). Babile further explains that on the 3rd of March 1976 the Ethiopian People's Revolutionary Party (EPRP) issued a public communiqué exposing the Derg's plan to unleash terror and to massacre the Ethiopian People's Revolutionary Party (EPRP) militants and sympathizers (Babile,1989:41). In a single sweep, Bible states that in Addis Ababa the same month troops killed about 1,000 students for distributing antigovernment leaflets. During the Red Terror in Addis Ababa, security forces frequently mutilated the bodies of political dissidents, dumping them along roads or stacking them on street corners. They also forced some victims to dig their own graves before being executed. The government required families to pay a "bullet fee" of about 125 birr to retrieve bodies of relatives, when they could be found and identified. Sweden's Save the Children Fund lodged a protest in early 1978 alleging the execution of about 1,000 children, many below the age of thirteen, whom the government had labeled "liaison agents of the counterrevolutionaries"(Babile,1989:41).

12Ethiopian Peoples' Revolutionary Party (EPRP) was the most popular among the various parties emerged in the 1960's. It was supported by a Paramilitary group called Ethiopian People's Revolutionary Army based at Asinba, in Eastern Tigray.

13 The terror was officially launched by the Derg in 1976 when it declared open war against the EPRP(Babile Tolla, 1989: 28) 


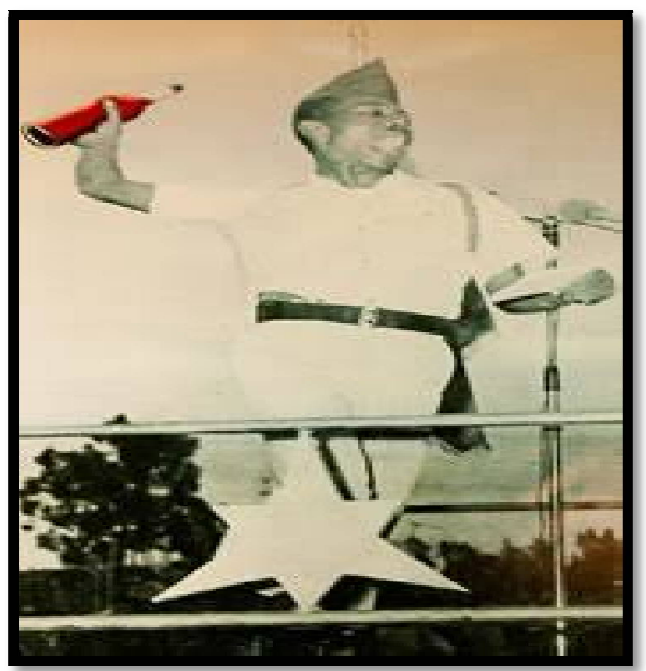

Figure 5: Col. Mengistu Declaring the Red Terror at Revolutionary Square, Addis Ababa (1983-84)

In fact, the assault included the Eritrean secessionist Shabia or the Eritrean People's Liberation Front (EPLF) Jebha or the Eritrean Liberation Front (ELF), the Monarchist Ethiopian Democratic Union (EDU), the Woyane or Tigrean Liberation Front (TPLF) and the Western Somali Liberation Front (WSLF) in his hunt along with the Ethiopian People's Revolutionary Party (EPRP).

"The students were hunted down, slaughtered, and left exposed to vultures all in order to preserve a text Book model of revolutionary will" (Soyinka, 1991:13).

1.3.The Failure of theEthiopian People's Revolutionary Party (EPRP) to Craft Strategic and Tactical Political Relations with Its Counterparts

From its very inception, the political relationship between Ethiopian People's Revolutionary Party (EPRP) and other political organizations was never an easy one. The Ethiopian People's Revolutionary Party (EPRP) is the product of Ethiopian student movement in the 1960's based at Addis Ababa University (AAU). Initially, it had attracted a great deal of attention by the progressive minded especially by students' from abroad. From the very beginning the Ethiopian People's Revolutionary Party (EPRP) felt psychologically superior by enjoying its vast support from its educated members as well as the Eritrean People's Liberation Front (EPLF). The Ethiopian People's Revolutionary Party (EPRP) underestimated the Tigray People's Liberation Front (TPLF) national oppression thesis and consider itself as a broad visionary with a bright and broad countrywide political agenda mobilizing and embracing the issue of class oppression and argued that national issue agendas would be solved when class oppression rooted out. Afterwards, the Ethiopian People's Revolutionary Party (EPRP) also put the Eritrean People's Liberation Front (EPLF) agenda below colonial issue and above national issue. Mulgeta in his Book of Galhatisegi stated the Ethiopian People's Revolutionary Party (EPRP) as it designatesitself Balck Bolsheviks and underestimated others especially the Tigray People's Liberation Front (TPLF) as narrow mined and outdated colonial oriented politics" (Galhatisegi,2010).

In fact, the failure of strategic and matured tactical relations with its counterparts put the Ethiopian People's Revolutionary Party (EPRP) endangered itself from different sides and its decision of making urban guerilla with the Provisional Military junta of the Derg led to the Red terror and its final demise. From its very inception, according to Mulgeta, the Tigray People's Liberation Front (TPLF) leadership has tried to talk with the Ethiopian People's Revolutionary Party (EPRP) leadership to narrow down its political difference and to work together for mutual political goal i.e. to topple down the military government. The first initiation for the political dialogue came from the Tigray People's Liberation Front (TPLF) leadership through Muse Tekle whereas the Ethiopian People's Revolutionary Party (EPRP) supposed to be represented by Birhane Meskel Reda, however, the Ethiopian People's Revolutionary Party (EPRP) refused to accept such a proposal from the Tigray Peoples Liberation Front(TPLF) and undermining its political objectives of the agenda of national oppression issues(Mulgeta,2002:91).The Eritrean People's Liberation Front (EPLF) also leaning towards to support the Ethiopian People's Revolutionary Party (EPRP) than Tigray Peoples Liberation front(TPLF) and even argued that the Ethiopian People's Revolutionary Party (EPRP) had broad political objectives and therefore other organization like Tigray People's Liberation Front(TPLF) should be subsumed under it. Initially, the Eritrean People's Liberation Front (EPLF) welcomed the Ethiopian People's Revolutionary Party (EPRP) and begun to provide military and moral support for it. The Ethiopian People's Revolutionary Party (EPRP) military wing i.e. the Ethiopian People's Revolutionary Army base was in Assinba in Eastern Tigray. 


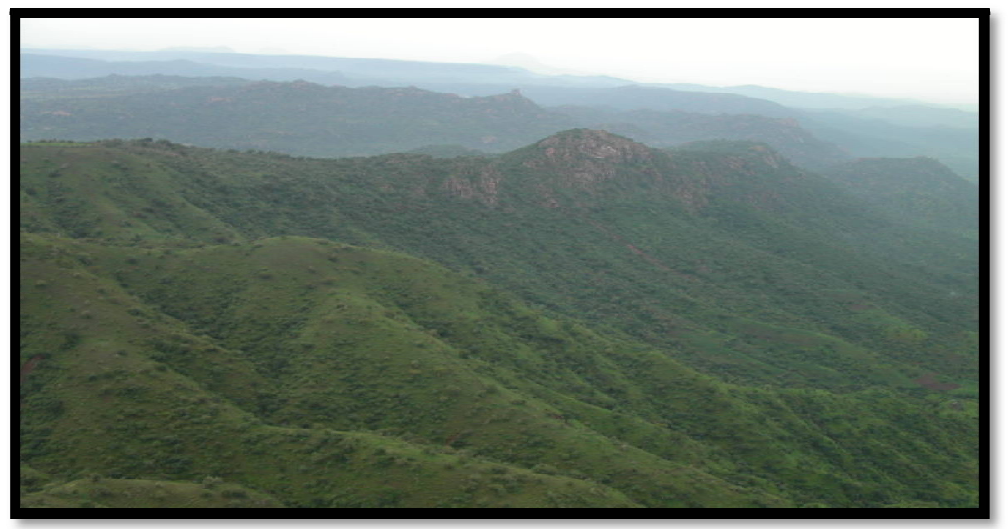

Figure 6: The Ethiopian People's Revolutionary Army (Epra) Military Base at Assinba In Eastern Tigray

Initially, the Ethiopian People's Revolutionary Party (EPRP) had mobilized democratic values. It had enjoyed a great deal of support from the Eritrean People's Liberation Front (EPLF) since it backed the Eritrean cause from its early inception. When the first squad of the Tigray People's Liberation Front (TPLF) received military training by the Eritrean People's Liberation Front (EPLF), 25 members of the Ethiopian People's Revolutionary Party (EPRP) had also received full military training by the Eritrean People's Liberation Front (EPLF). Those 25 trainees also got military training and support from the Palestine Liberation Front later organized into the Ethiopian People's Revolutionary Army (EPRA) stationed on its first military base at Assinba in Eastern Tigray. Fully armed, in 1967 those 25 squads accompanied by the Eritrean People's Liberation Front (EPLF) finally stationed in Eastern Tigray at Asinba ${ }^{14}$. In their stay at Assinba the Ethiopian People's Revolutionary Army (EPRA) enjoyed a continued support that came from the Eritrean People's Liberation Front (Mulgeta, 2002:116). The Ethiopian People's Revolutionary Party (EPRP) vs Tigray People's Liberation Front (TPLF) initial stag relationships and political discussions occurred in Eritrea when both squads received military training by the Eritrean People's Liberation Front (EPLF). Following this other irregular relations and political discussions held and continued in the first months of 1968. On the first month of September 1968, Siyoum, Seberom, Tsihaye had discussed about the two parties' political objectives and mobilizations with the Ethiopian People's Revolutionary Party (EPRP) leadership near Sobia (Mulgeta,2002:117). Following that, in a few months, both leaderships had political talks with the presence of the Eritrean People's Liberation Front (EPLF) representatives such as Dr. Eyob and Baraki. The delegates of the Tigray People's Liberation Front (TPLF) were Giday Zeratsion, Abay Tsahaye, Ag Azi, and Sibhat Nega; whereas the representatives of the Ethiopian People's Revolutionary Party (EPRP) were Birhane Eyasu,Tsegaye G/ Medhin (Roba), Tsegay Mehari, and G/ Egzabhier (Gayim). According to Mulgeta, the Tigray People's Liberation Front(TPLF) leadership focused mainly on the issue of reducing political differences to work together with peaceful relations with proper military tactic and strategy, and the Tigray People's Liberation Front (TPLF) initially believed the Ethiopian People's Revolutionary Party (EPRP) would better of its attitudes towards its organization(Mulgeta,2002:217). However, the Ethiopian People's Revolutionary Party (EPRP) leaderships take different directions claiming their struggle covered the whole Ethiopia. As to them, it was meaningless and premature to raise the national oppressionthesis and the Ethiopian People's Revolutionary Party (EPRP) designated itself as black Bolsheviks where as they labelled the Tigray People's Liberation Front (TPLF) as narrow nationalists. However, both the Tigray People's Liberation Front (TPLF) and the Ethiopian People's Revolutionary Army (EPRA) have reached an agreement to mobilize their respective army near Sobia, Asinba and the surrounding area without any aggression and military hostility.

According to Medhane, the Eritrean People's Liberation Front (EPLF) preferred to deal with the Ethiopian People's Revolutionary Party (EPRP) since at that stage it was a promising organization which led many observants to believe that sooner or later it would topple the military government of the Derg (Medhane,1999:59). Later on, the Ethiopian People's Revolutionary Party (EPRP) focused on urban guerilla to take political power with a short cut and soon began its mission in many urban centre of the country. The Derg military junta's response was very harsh that led to the red terror were thousands of educated young people hunted down with show of force. At the meantime in a meeting held at Asmera, the Ethiopian People's Revolutionary Party (EPRP) put the Eritrean People's Liberation Front (EPLF) political secessionist struggle below colonial issue and above national issue. Following that decision, after a preliminary assessment of the political situation the Eritrean People's Liberation Front (EPLF) turned its face from the Ethiopian People's Revolutionary Party (EPRP) later gave its full military support to Tigray Peoples Liberation Front (TPLF). Meanwhile the Ethiopian People's Revolutionary Party (EPRP) political leadership had begun to disintegrate from within and this was accompanied by the decision of urban guerrilla war against the military junta in different city centres was a fatal political mistake that marked to its final piteous demise.

${ }^{14}$ Assinba meaning "the Red Hill" was the first military base situated in Eastern Tigray were the Ethiopian People's Revolutionary Army(EPRA) first stationed in 1967. 


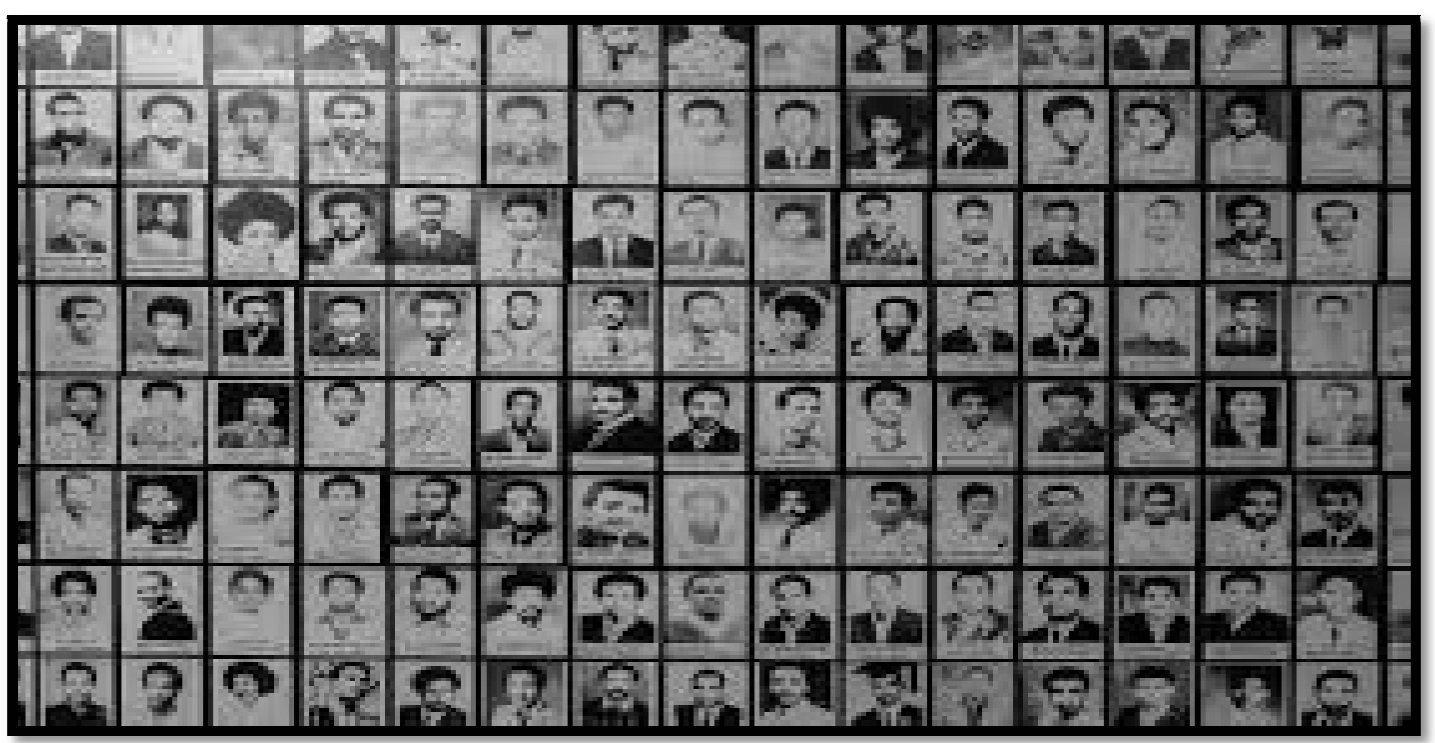

Figure 7: Victims of The Red Terrorand the Red Terror Martyrs

Source: The Addis Ababa Martyrs Memorial Museum 2017

Ethiopia under the socialist oriented military government of Mengistu had one of the worst human rights records in the horn of Africa. The military government ruled Ethiopia with decrees and proclamations for more than thirteen years. Eventhough the 1987 constitution came into being and introduced to some basic freedoms and rights and also grant some recognition of the human rights issues, it remained solely on paper and the three branches of the government organs were not separated. Generally speaking, human rights violations after 1974, according to Amnesty International, and the International Committee of the Red Cross it deteriorated further from 1976 to 1978.

\section{The Invasion of Somalia and the Communist Bloc Military Assistance to Ethiopia}

Before 1974 Ethiopia's relation with the neighbouring Somalia, bordering to the East, had been calm. This was because of the wise king of Haile Silassie and partially also because of the Article of Organization of Africa Unity that declared, "Borders which was left by the European colonial powers should be respected" (OAU, 1963). The OAU15 has been particularly significant in decolonization. It was the instrument of the governments on behalf of their people to liberate the remaining African countries. The year 1960 was called "African year" because many African countries gained at least political independence, however, they were busy in border dispute and irredentism claim. That's why in order to calm the above volatile political situation the Organization of Africa Unity came up with such an Article. During the 1950s, 1960s and 1970s many African countries fought bitter wars to gain independence from their colonial rules. Following independence, many political tensions, which had been subdued by colonialism, manifested themselves in civil conflicts. Countries such as Angola, Mozambique, Ethiopia and Sudan were torn apart by conflict. In post-independence Africa a number of military coups and conflicts have occurred and much of this conflict in Africa was aggravated by super power rivalries. The United States and the former United Soviet Socialist Republic took side with opposing factions in individual countries and showed their support by providing military hard ware and training. The United States and Soviet Russian interests dominated the continent in general and the horn of African in particular. As a result of this, many African states seeking to survive and expand their power by making political alignment with any one of the super powers. Alignment occurs when a state brings its policies in close cooperation with another state in order to achieve mutual security goals and benefits. Balance of power theory argues that states align to protect themselves against the power of or treats from other states. The most powerful determinant of third world alignment and realignment behaviour according to Steven $R$. David is that, the rational calculation of third world leaders as to which outside power is most likely to do what is necessary to keep them in power (David, 1999:235).

The problem of Ethio-Somali border conflict would go back to the end of 19th century. When the British Somali land as well as French Somali land established, afterwards Britain created the Somali youth league and the idea of greater Somali was born from this league. During World War II the Italian force stationed mainly on Eritrea and Ogaden regions but after defeated by the British and the Ethiopian patriots, the British East Africa Enemy Territory Administration was established. Finally, when the British force left these areas, it restored to Ethiopia. However, it was mainly intensified with the formation of Somali Youth League. The frontier quarrels between Somalia and its neighbours in general and Ethiopia in particular was Somalia's desire for "Greater Somalia" through a union with all the lands inhabited by Somali tribes in the neighboring countries. Such kind of nationalist-irredentist policy of Somalia was attributed with the territorial fragmentation and penetration of the Somalias' by the British, French and Italians. The breakdown of the horn in general and especially the three major states in particular such as Ethiopia, Somalia and Sudan are due to, according to Woodward, to the ravages of civil war. He argues that, while all three conflicts arise from domestic issues, their scale has been

${ }^{15}$ The OAU was established in 1963 headquartered in Addis Ababa. The OAU established by the foremost thinkers of Pan-Africanism who played a crucial role for the liberation of African countries from European colonial rule. 
magnified by international involvement which has also linked the three countries together, with Ethiopia as the strategic geographical setting center (Peter Woodward, 1996).

Somalia, with its dictator Siyad Bare ${ }^{16}$, invaded Ethiopia in 1977 in the view of establishing greater Somalia. It was a kind of irredentism claim of Ogden region, i.e. Somali speaking inhabited part of Ethiopia. This was similar with that of Hitler who claimed Sudeten land, which was, German speaking part of Czechoslovakia in order to help him to get a launching pad in order to invade the whole part of the country which was proofed in March 1938. The invading force of Somalia moved success after success and invaded many regions and reached Awash River to the South of the capital Addis Ababa. The communist bloc provided the military government of Mengistu with massive help which included a force of up to two-thousand Cuban professional mercenaries and the Soviet Union military hardware. "The Soviet Union provided large scale military support to Ethiopia including tanks and jet air craft at a cost of \$ 1 billion" (Henry, 1978:453). As a result of the military assistance the Communist Bloc gained much more influence in Ethiopia. Ethiopia with its military assistance of the Communist Bloc gave a harsh military response to Somalia. Somalia was decisively defeated in a village called Kara Mara near Ogaden province. However, the decision of the Soviet Union to support Ethiopia in the struggle between the two Countries led to expulsion of Russia from Somalia and loss of the Soviet Union position on the North East Indian Ocean littoral. The Soviets and the Cubans launched an unprecedented arms and personnel airlift to come to Ethiopia's rescue. Bienen Henry put it in his own words, "Massive Cuban involvement in to Ethiopia, led to a shift in the United States policy in 1978" (Henry, 1978:444).

The Derg regime turned back the Somalia invasion, and made deep strides against the Eritrean secessionists and the Tigrean Liberation Front. By the end of the seventies, Mengistu presided over the second largest army in all SubSaharan Africa, and a formidable air force and a navy as well. This military assistance provided Russia a fertile political ground to consider socialist oriented Ethiopia as their strategic ally for their political strategy for further development in the horn of Africa. Russia involved more in the domestic affairs of the Country much higher than before in the hope that Ethiopia's socialist example would help to spread out communism to other regions of East Africa.The Ethiopian Revolutionary Army, with the extraordinary assistance of thousands of Cuban and soviet advisors and troops, not only defeated the Somali invasion but also suppressed the remaining insurgency using a combination of military and nonmilitary operations.

\subsection{The Overthrow of the Military Government and the End of Socialist Experiment in Ethiopia}

Quite a lot of Internal and external political factors led to the collapse of the military government of Ethiopia in 1991. Internally, the military government was faced with enormous difficulties throughout the 1980s in the form of droughts, wide spread famine, the growing internal dissatisfaction of the army.In addition to that the brutal reign of terror followed by the carnage response for every socio-economic and political quest disable the socialist government to get social support from the people. Whereas externally, the end of the cold war and the subsequent collapse of the former United Soviet the Socialist Republic in 1989 hastened the inevitable collapse of the socialist military government. As Mengistu himself once put it, the insurgents did not win; the army lost. According to him defeat was brought about difficult terrain, combat fatigue, internal discord and perfidy or subversion from within. However, the biggest reason for the defeat of the military government according to Mengistu was the betrayal by some of their own authorities whom in their eagerness to destroy their own government and party, delivered victory to the bandits on a platter. This was no doubt an allusion to the failed plot of 1989, but by then both the regime and the army were terminally ill and the event merely hastened their deaths (Gebru, 2016:312)

In fact, it was too late to introduced the socialist political ideology and command economy to East Africa at this time because by the 1970's communist dominations of Russia in Eastern Europe were in a big question. For instance, the Hungarian uprising by 1956, the Prague spring in 1968, and the Polish resistance and respective East and central European state deviation from the communist bloc were the challenges bitter for Russia to swallow. The death of Stalin and the emerging criticism followed by destalinization process speeded up its disintegration. Economic dissatisfaction changed the political atmosphere of Eastern European Countries. Meanwhile, Mikhail Sergeyevich Gorbachev came with the idea of glasnost and priosterica ${ }^{17}$ which is openness and restructuring respectively. These Reform policies intensified in Eastern and Central European Countries. The Socialist military government of Ethiopia which was heavily depended on the Soviet Russia and also backed by Eastern Germany and observed the highest military support now lost control of the government.

Following the collapse of East Germany in 1989, the socialist military governments of Ethiopia internal position deteriorated. According to the words of Richard Pipes by 1991 when the Soviet Russia dissolved the Ethiopian ruler found himself isolated (Pipes, 2000:145). Ethiopia predominantly an agrarian economy was on the verge of collapse followed by an aggravated drought resulted in famine 1984-1985 by which nearly thousands of Ethiopians perished. By using this fertile condition, the former Tigray Peoples Liberation Front now organized in to Ethiopian People's Revolutionary

\footnotetext{
${ }^{16}$ The Somali dictator Siyad Bare was the product of the Somali Youth League which was established by Britain in 1947. Siyad Barre used the Ogaden region of Ethiopia as an excuse to invade the area. However, the motive behind the invasion was an irredentism claim to control the fertile resource in the area. The Ethiopian military government response was tough supported by Cuba and other socialist countries.

${ }^{17}$ Perestroika meaning restructuring and glasnost meaning openness was a political movement for reformation within the Communist Party of the Soviet Union during the 1980s and 1990s and has been widely associated with Soviet leader Mikhail Gorbachev and his glasnost policy reform. The perestroika is referring to the restructuring of the Soviet political and economic system. Perestroika is sometimes argued to be a significant cause of the dissolution of the Soviet Union, the revolutions of 1989 in Eastern Europe, and the end of the Cold War.
} 
Democratic Front, joined together with the Eritrean liberation front began pushing forward to give a final hit to the socialist regime. They were military supported by the United States and the Western World.

To control the situation Mengistu tried to introduce a sort of mixed economic policy. Some sources indicate this was done after an advice by Fidel Castro of Cuba. Within that brief period a text Book was printed and introduced that ponder partly about free market economy and partly Command economy, however this strategy was not enough to save the military socialist government. Following years of wide scale drought, economic failures, and brutal corps the regime was finally toppled in 1991 by a coalition of rebel forces. Mengistu fled the country with his Derg officials and was granted political safe haven in Zimbabwe, as an official guest of Robert Mugabe. Mengistu established good relationship with Mugabe in the 1980's. He sent Ethiopian troops when Zimbabwe fought for independence in 1980. In May 1991, Ethiopian People's Revolutionary Democratic Front forces advanced to Addis Ababa. Mengistu himself blames the collapse of his government on Michael Gorbachev for letting the Soviet Union collapse and hence cutting of its aid to Ethiopia.

\section{Conclusion}

Socialist system is based on the welfare of the whole society and that's why it was believed as a more efficient system in which the state should be governed by one political entity that would regulate everything for the best of the population. In theory the premise is not bad at all, but the problem becomes visible when it was applied. The following sentence attests by Cornwell that Russia provides an example in herself of how communism can develop a country (Cornwell, 1980:346). The socialist government of Ethiopian ideological leaning to the former United Soviet Socialist Republic may have made it more comfortable with the Soviet Union, but there is no evidence that it played an important role for Ethiopia for its political alignment. Instead, the influence of socialism ideology with its command economy brought to Ethiopia difficult experience. Ethiopia suffered as a result of its alignment with the Soviet Union that led the Socialist leaders to put the economy of the country in to war field for nearly two decade. Communism was officially adopted during the late 1970's and early 1980's with the promulgation of a Soviet style Constitution, a politburo, and the creation of workers Party of Ethiopia. All foreign owned companies were nationalized without any compensation. Several opponents of the socialist military government were indiscriminately brutally crushed. Peoples in a state of subjugation have neither freedom nor responsibility. Economically, Soviet Russia's communist influence brought to Ethiopia and manifested at the lowest level of economic development. This was especially aggravated by the Socialist military government by putting the country's economy in to the war field. According to Gebru, the mobilization of so vast a number of men extensively upset the nation's economic and social order without increasing the military's capacity 18 to prevail (Gebru, 2016:133).

Politically, the country's situation was deteriorated by adopting bizarre systems and new socialist political ideologies which has been characterized by unstable, dangerous and fatal to its own citizens. Socially, throughout the Ethiopian history the church was the most important ideological instrument for the state. Prior to the adoption of the socialist experiment in 1974, the church matches with the states and the church again matched with the culture. Socialism during the military government, however, led to the closing of many churches and followed a confusing period among the believers.

\section{References}

i. Gebru Tareke (2016) The Ethiopian Revolution: War in the Horn of Africa. Eclipse Printing Press. Addis Ababa, Ethiopia.

ii. Babile Tola (1989) To kill a Generation: The Red Terror in Ethiopia. FREE ETHIOPIAN PRESS. Washington, D.C.

iii. Tasfaye Makonnen (1985) Yedras LaBalatariku (May It Reach the Protagonist). Addis Ababa, Ethiopian.

iv. Mulgeta Debalkew (2002) Galhati Segi Ye Hiwuhat Yetitk Tigil Tarik (1967-1983). Gal Hati Segi: The Armed Struggle History of the TPLF (1975-1991)

v. Taklo Teshome (2005) Ye Dem Zemen (Era of Blood). Ye Chenegefe Rayi; Yal tequache Tarik (The Aborted Vision and the Unfinished History). Part I. Melbourne, Australia.

vi. Friedmann, W. (1953) An Introduction to World Politics. St. Martin's Press INC. The Macmillan Company of Canada limited, Toronto.

vii. Eshetu, Chole (2004) Underdevelopment in Ethiopia. Organization for Social Science Research in Eastern and Southern Africa. Printed in Ethiopia Addis Ababa.

viii. Balsvik Randi Ronning (2007) The Quest for Expression: State and the University in Ethiopia under three Regimes 1952-2005. Addis Ababa University Press.

ix. Bahru Zewde (2000) A History of Modern Ethiopia. Ohio University Press. Addis Ababa.

x. Kiflu Tadesse (1993) The Generation. The History of the Ethiopian People's Revolutionary Party. Part I. From the Early Beginnings to 1975.

xi. Kiflu Tadesse (1998) The Generation. The History of the Ethiopian People's Revolutionary Party. Part II. Ethiopia: Transformation and Conflict. Lanham.

xii. Clapham, Christopher (1988) Transformation and Continuity in Revolutionary Ethiopia. Cambridge.

xiii. Teferra Haile-Silassie (1997) The Ethiopian Revolution 1974-1991. From a Monarchial autocracy to a military Oligarchy. London.

${ }^{18}$ Almost more than five hundred thusand strong revolutionary army through out the the diffrent parts of the country consumed the ecountry's economy for seventeen years without increasing the the military's cpacity. Initially, the army was able to pacify the whole countryside. 
xiv. Bahru Zewde (1998) The Military and Militarism in Africa: The Case of Ethiopia, in Eboe Hutchful and Abdoulaye Bathily, eds., The Military and Militarism in Africa. Dakar.

xv. Young, John (1997) Peasant Revolution in Ethiopia: The Tigray People's Revolution Front,1975-1991. Cambridge: Cambridge University Press.

xvi. Medhane Tadesse (1999) The Ethiopian-Eritrean war: Retrospect and Prospects. Reflections on the Making of Conflicts in the Horn of Africa,1991-1998.Printed by Mega Printing Enterprise Addis Ababa, Ethiopia.

xvii. Richard Pipes (2000) Communism: A History: Random House Publishing

xviii. Steven R. David (1999): Explaining third World Alignment: John Hopkins University Press, No65 pp 233-265

xix. Richard Pipes (1995) A Concise History of The Russian Revolution; Vintage House Publishing; A division of Random House, Inc. New York

xx. Henry Bienen (1978) US Foreign Policy in a Changing Africa: Vol, 93, No3; The Academy of Political Science P 443464.

xxi. R. V. Burks (1961) The Dynamics of Communism in Eastern Europe. Princeton: N.J. Princeton University Press

xxii. Soyinka Wole (1991) Beyond the Berlin Wall

xxiii. David Marcus (2003) Famine crime International Law

xxiv. R.D. Cornwell (1980) World History in the 20th Century. Singapore: Singapore Publishers' Pt. Ltd

xxv. Rupert Emerson (1966) Dilemmas of American Policy in Africa. Duke University Press; No. 25 (1966), PP. 10-16

xxvi. Roger W. Benjamin and John H. Kautsky (1968) American Political Science Association. The American Political Science Review

xxvii. Peter Woodward (1996) The Horn of Africa Politics and International Relations Peter Woodward 1996 British Academic Press, International Library of African Studies.

xxviii. Rupert Emerson (1966) Dilemmas of American Policy in Africa. Duke University Press,

xxix. Merera Gudina (2003) Ethiopia. Competing Ethnic Nationalisms and the Quiet for Democracy 1960-2000. Shaker Publishing, Reprinted and bound in Ethiopia by Chamber Printing House. 